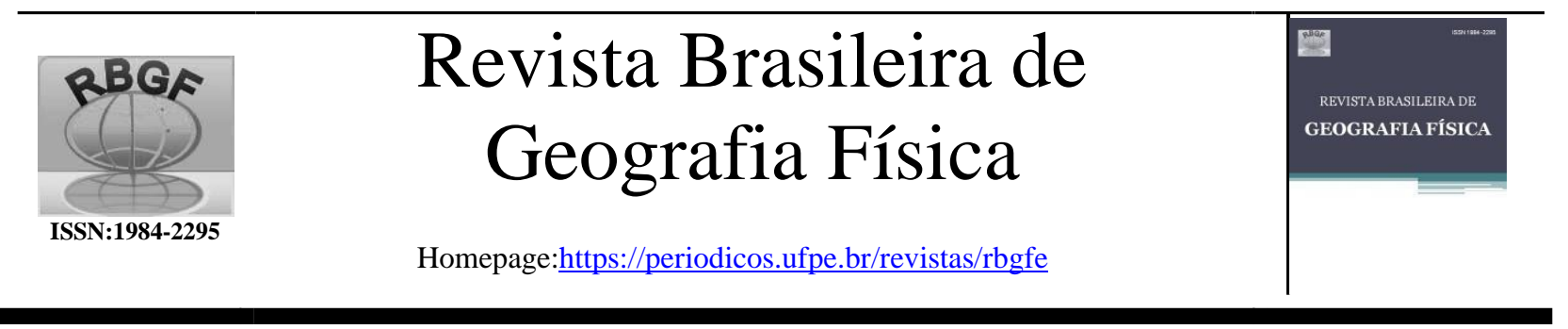

\title{
Landscape dynamics of the Cajuri city, Minas Gerais, Brazil
}

\author{
Ricardo Oliveira Rosa ${ }^{1}$, Jaqueline Aparecida de Oliveira ${ }^{2}$, Kleber Mariano Ribeiro ${ }^{3}$
}

\begin{abstract}
${ }^{1}$ Master student, Zootechnics Department of the Federal University of Viçosa, Av. Peter Henry Rolfs, University Campus, Viçosa, Minas Gerais, 36570-900. Phone: +5531 3612-4621. ricardo.ifsudestemg@ gmail.com (corresponding author). ${ }^{2} \mathrm{PhD}$ student, Microbiology Department of the Federal University of Viçosa, Av. Peter Henry Rolfs, University Campus, Viçosa, Minas Gerais, 36570-900. Phone: +55 $313612-5054$. jaqueline.a.oliveira@ufv.br. ${ }^{3} \mathrm{PhD}$ in Agricultural Engineering, Agriculture and Environment Department, Federal Institute of Southeast of Minas Gerais, Dr. José Sebastião da Paixão, Lindo Vale, Rio Pomba, Minas Gerais, 36180-000. Phone: +55 323571 5790. kleber.ribeiro@ ifsudestemg.edu.br. Artigo recebido em 31/05/2021 e aceito em 13/12/2021
\end{abstract}

\section{A B S T R A C T}

The present paper aimed to evaluate the landscape dynamics of the city of Cajuri, Minas Gerais, Brazil. For this, a digital image of the Sentinel-2A satellite, dated June 2020, was classified to map the current land use in the municipality and the areas of pasture, native forest, annual and perennial crops, coffee and urban extension were quantified. The data collected were compared with historical records made available by public sectors for the analysis of the dynamics of land use. Pastures (35.24\%) and native forests (28.74\%) occupy 63.98\% of the territory of Cajuri. Part of the agricultural activities are in the environmental areas and require attention for the sustainability of the practices. Except for the urban area, all classes mapped have increased their occupation areas recently and in succession mainly to the citrus areas. The information presented can be used to assist in decision making, planning and strategic studies in the city.

Keywords: classification, land use, transformation, time series.

\section{Dinâmica da paisagem do município de Cajuri, Minas Gerais}

\section{R E S U M O}

O objetivo do presente trabalho foi avaliar a dinâmica da paisagem do município de Cajuri, Minas Gerais, Brasil. Para isso, uma imagem digital do satélite Sentinel-2A, datada de junho de 2020, foi classificada para o mapeamento do uso da terra atual do município e as áreas de pastagens, mata nativa, culturas anuais e perenes, café e extensão urbana foram quantificadas. Os dados levantados foram confrontados com registros históricos disponibilizados pelos setores públicos para a análise da dinâmica do uso da terra. Pastagens $(35,24 \%)$ e matas nativas $(28,74 \%)$ ocupam 63,98\% do território de Cajuri. Parte das atividades agrícolas estão nas áreas ambientais e requerem atenção para a sustentabilidade das práticas. Com exceção da área urbana, todas as classes mapeadas aumentaram suas áreas de ocupação recentemente e em sucessão das áreas de citros. As informações apresentadas podem ser utilizadas para auxiliar na tomada de decisões, planejamentos e estudos estratégicos no município.

Palavras-chave: classificação, uso da terra, transformação, série temporal.

\section{Introduction}

Cajuri is a Brazilian city located in the Zona da Mata mesoregion, Viçosa microregion, and there is a favorable climate and soil for the development of agricultural activities. In the decade of 1960, agricultural production of Cajuri was diversified and there were citrus, coffee, sugar cane, beans, maize and vegetables occupying prominent places in the city economy, however, today, coffee, tomatoes and dairy cattle are the main agricultural activities developed (Fialho et al., 2016, Pereira et al., 2018, Freitas et al., 2018, Coutinho and Carvalho, 2019, EMATER, 2019, EMATER 2020), with the creation of employment, taxes and exchange revenues (Fialho et al., 2016, Pereira, 2020).

This dynamic in the agricultural activities developed in the city is associated with the adaptations of a recently formed society - Cajuri 
was emancipated in 1962 - and the economic demands of the time, which it brought, as a result, the socioeconomic development and also significant changes in the local landscape. Papers such as those carried out by Coelho et al. (2005), in which the authors identified less than $20 \%$ of natural forest cover in the Cajuri city and the lowest rate of natural forest increase among the cities that make up the Viçosa microregion, Campos et al. (2006), in which the researchers observed the exhaustion of the nutrients in the local soil after clearing forests to intensify economic activities in the city, and Ribeiro et al. (2014), in which the team indicated agricultural and pasture areas in $60.26 \%$ of the permanent preservation areas (PPA) of the Sertão stream watershed, are some records of this environmental impact generated by agricultural activities in the Cajuri city.

The expansion of the economic activities without planning and in a disorganized way over natural landscapes brings the reduction or even extinction of the ecosystem resources, the basis for the life maintenance (Ferreira et al., 2019, Silva and Gameiro, 2021). In this context, the society needs to be aware and committed to sustainable development and integrate economic actions with available natural resources (Reis and Ribeiro, 2016, Haetinger et al., 2021) for the future continuity of the activities, which involves the space-time perception of as the soil has been occupied, as highlighted by Brito et al. (2016).

Landscape mapping search to quantify and graphically describe the spatial distribution of land use in a given region and, when associated to the previous records of the land occupation, it allows us to understand the spatio-temporal transformations and create subsidies to project the future (Furtado et al., 2020, Maidjelele et al., 2020). The area occupation within the agroecosystems potential (Brito et al., 2016, Barros et al., 2019), the actions organization of technical assistance and rural extension (Costa Jr. et al., 2018), the inspection, management and environmental recovery (Leite et al., 2010, Cândido et al., 2016, Vivas and Nunes, 2018) and the agroeconomics strategies are some activities that begin in the space-time history of land use.

Coelho et al. (2005) and Ribeiro et al. (2014) are some papers that address land use and occupation in the Cajuri city, and that can be combined with information from agricultural reports and survey of current landscape data for the construction of a space-time series of the land use that supports the understanding of the transformations that have occurred, the current decisions making and the planning of the future actions.

Graphic representation of the landscape of a region can be performed using geoprocessing techniques (Neto et al., 2019, Miranda et al., 2020) and papers such as those accomplished by Justino et al. (2019), in the survey of the land use and of the permanent preservation area (PPA) in the São Tomé and Machado rivers watersheds, in Minas Gerais, Brazil, Folharini and Souza (2019), in the study of land occupation in the Petrolina city, Pernambuco, Brazil, Silva et al. (2020), in the mapping of the land use and occupation of the Água Branca river watershed, in Bahia, Brazil, and Costa et al. (2021), in the landscape mapping of the Serra river watershed, in Morrinho city, Goiás, Brazil, illustrate the potential of this tool in mapping land use.

In geoprocessing, the geographic information processing and the spatial and temporal correlations between the information plans occur in dedicated environments called the geographic information system (GIS) (Aragão, 2020). Among the several GIS available on the market, Quantum GIS has been gaining contrast and providing tools for the patterns recognition and the formation of clusters with similar characteristics (QGIS, 2021).

In this context, the present paper aimed to evaluate the landscape dynamics of the Cajuri city, Minas Gerais, Brazil, through the current mapping of the city land use, using geoprocessing techniques and using Quantum GIS, and integrating these results with previous records.

\section{Material and methods}

Cajuri is located between the geographic coordinates $20^{\circ} 44^{\prime} 35^{\prime \prime}$ and $20^{\circ} 49^{\prime} 39^{\prime \prime}$ of south latitude, $42^{\circ} 40^{\prime} 36^{\prime \prime}$ and $42^{\circ} 49^{\prime} 57^{\prime \prime}$ of west longitude and at 721 meters of medium altitude, integrates the Brazilian biome of the Atlantic Forest and the Doce river watershed (IBGE, 2021). The city has an area of $83,038 \mathrm{~km}^{2}$, humid subtropical climate with rainy summers, dry winters and receiving the designation $\mathrm{Cwa}$ in the Köppen-Geiger classification (Fernandes et al., 2007) - and the soil predominant in the territory is the red yellow latosol (Santos et al., 2013). Figure 1 illustrates the geographic location of the study area. 

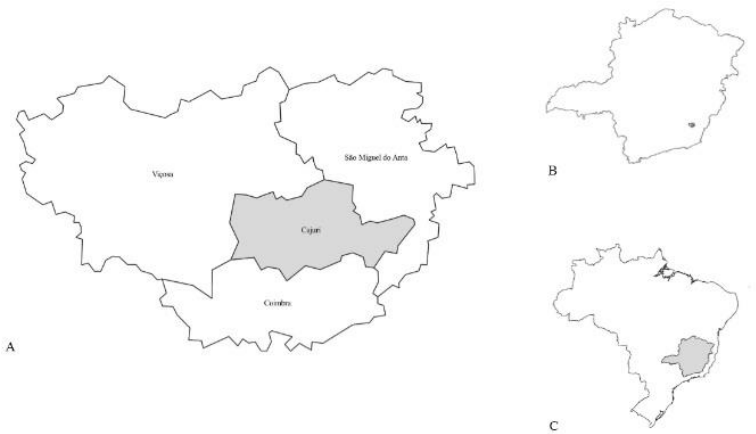

Figure 1. Geographic localization of the Cajuri city (A), Minas Gerais (B), Brazil (C).

Vector data of the limits of the Cajuri city, obtained on the website of the Brazilian Institute of Geography and Statistics, and the digital image of the Sentinel-2A satellite, Multi-Spectral sensor (MSI) and dated June 12, 2020, were used for the current mapping of land use. Free access, the 10 meter of spatial resolution and the papers carried out by Borges et al. (2017) and Pereira and Guimarães (2018) motivated the adoption of this digital scene in this survey.

Agricultural series and the records in public agencies of the emerging crops in the city guided the definition of the six (6) classes adopted in this study, namely: pasture, native forest, annual crops (maize, beans and tomatoes), coffee, perennial crops (eucalyptus, banana, heart of palm and sugar cane) and urban area. The classes were manually delimited in a GIS and despite being a perennial crop, the coffee tree was analyzed separately here, given its economic importance in the Cajuri city.

The area of each class surveyed and its percentage of occupation in relation to the total area of the city were estimated to support the quantitative analysis of the current landscape classification of the municipality of Cajuri. In addition, 30 reference points (5 for each delimited class) were randomly sampled on the land use map to assist the qualitative interpretations, in which the global accuracy and Kappa index (Cohen, 1960), expressed mathematically in Equations 1 and 2, were used to observe the representativeness of the results found.

$$
\mathrm{GA}=\frac{\sum \mathrm{X}_{i}}{N} \cdot 100
$$

In which:

GA corresponds to the global accuracy, in \%;

$\sum X_{i}$ is the representative observations number in the field, dimensionless;

$\mathrm{N}$ is the total number of reference points, dimensionless.

$$
k=\frac{N \sum X_{i i}-\sum X_{i+} \cdot X_{+i}}{N^{2}-\sum X_{i+} \cdot X_{+i}}
$$

In which:

$\mathrm{k}$ consists of the Kappa index, dimensionless; $\sum X_{i i}$ is the sum of the correct observations in the diagonal of the confusion matrix, dimensionless; $\sum X_{i+}$ is the linear sum, dimensionless; $\sum X_{+i}$ is the collinear sum, dimensionless.

Global accuracy varies between $0 \%$ and $100 \%$ and the high GA values are associated with the representativeness of the classification performed. In the evaluation of the Kappa index, which varies between the null and the unit, the classification of the agreement follows that established by Landis and Koch (1977) in Table 1.

Table 1. Kappa indexes and its levels of agreement.

\begin{tabular}{cc}
\hline Kappa indexes & Agreement \\
\hline$<0.0$ & None \\
$0.0<\mathrm{k} \leq 0.2$ & Slight \\
$0.2<\mathrm{k} \leq 0.4$ & Fair \\
$0.4<\mathrm{k} \leq 0.6$ & Moderate \\
$0.6<\mathrm{k} \leq 0.8$ & Substantial \\
$0.8<\mathrm{k} \leq 1.0$ & Almost perfect \\
\hline
\end{tabular}

Source: Landis and Koch (1977).

Environmental preservation areas for the conservation of natural resources (Brazilian Federal Law No. 4,771/65) - such as areas close to the water courses, regions with slope greater than $45^{\circ}$ and hill tops - were also mapped to assist in the analysis of the landscape environmental dynamics of Cajuri. In the mapping of the riparian PPA were considered 30 meters on each side of the main water resources and 50 meters around the springs, TOPODATA data, from the Brazilian Institute for Space Research, were used in the survey of plains with a slope greater than $45^{\circ}$ and the hill top areas followed the guidelines proposed by Silva et al. (2017).

Results of the current landscape of the city were compared with the literature, such as Coelho et al. (2005) and Ribeiro et al. (2014), with Agricultural Censuses from the Agriculture Department of Minas Gerais and Brazilian Institute of Geography and Statistics and with agricultural records from the City Hall to analyze the landscape temporal behavior of Cajuri. 
Descriptive statistics were used in the quantitative assessment of the landscape changes over time and all processing of the geographic information was performed using the Quantum GIS, version 3.4 (QGIS, 2021), and its internal plugins GRASS and SAGA, and its internal plugins GRASS and SAGA.

\section{Results}

Figure 2 illustrates the spatial distribution of the current land use and Table 2 shows the contribution of each class to the current landscape of the Cajuri city, Minas Gerais, Brazil.

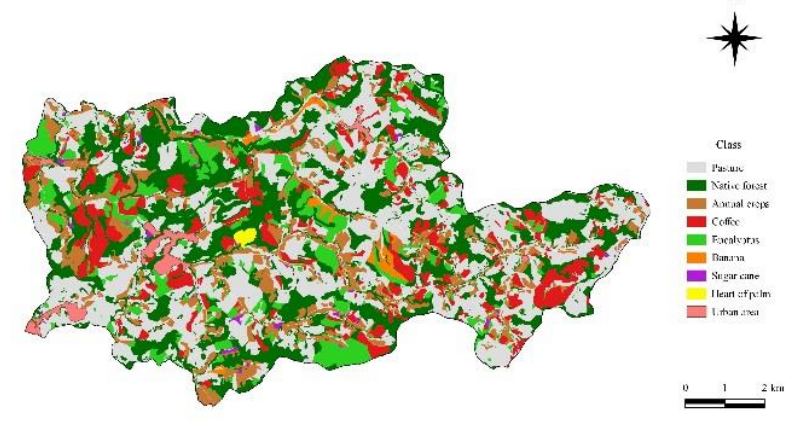

Figure 2. Current land use in the Cajuri city, Minas Gerais, Brazil.

Table 2. Contribution of the mapped classes to land use in the Cajuri city, Minas Gerais, Brazil.

\begin{tabular}{|c|c|c|c|}
\hline \multicolumn{2}{|c|}{ Class } & $\begin{array}{c}\text { Area } \\
\text { (hectares) }\end{array}$ & $\begin{array}{c}\text { Percentage } \\
(\%)\end{array}$ \\
\hline \multicolumn{2}{|c|}{ Pasture } & $2,926.63$ & 35.24 \\
\hline \multicolumn{2}{|c|}{ Native forest } & $2,386.85$ & 28.74 \\
\hline $\begin{array}{l}\text { Annual } \\
\text { crops }\end{array}$ & $\begin{array}{c}\text { Maize } \\
\text { Beans } \\
\text { Tomatoes }\end{array}$ & 985.31 & 11.87 \\
\hline \multicolumn{2}{|c|}{ Coffee } & 865.95 & 10.43 \\
\hline \multirow{3}{*}{$\begin{array}{l}\text { Perennial } \\
\text { crops }\end{array}$} & $\begin{array}{c}\text { Eucalypts } \\
\text { Banana }\end{array}$ & $\begin{array}{l}712.96 \\
81.43\end{array}$ & $\begin{array}{l}8.59 \\
0.98\end{array}$ \\
\hline & $\begin{array}{l}\text { Sugar } \\
\text { cane }\end{array}$ & 48.88 & 0.59 \\
\hline & $\begin{array}{c}\text { Heart of } \\
\text { palm }\end{array}$ & 18.22 & 0.22 \\
\hline \multicolumn{2}{|c|}{ Urban area } & 85.79 & 1.03 \\
\hline \multicolumn{2}{|c|}{ Total classified: } & $8,112.02$ & 97.69 \\
\hline \multicolumn{2}{|c|}{ Total unclassified: } & 191.78 & 2.31 \\
\hline \multicolumn{2}{|c|}{ TOTAL: } & $8,303.80$ & 100.00 \\
\hline
\end{tabular}

Land use mapping in the Cajuri city (Figure 2) showed a kappa index equal to unit, a global accuracy of $100 \%$ and the classification occurred in $97.69 \%$ of the Cajuri territory (Table 2).

The mapping shows that pastures $(2,926.63 \mathrm{ha})$ and natural forests $(2,386.85 \mathrm{ha})$ are the predominant landscapes and together they occupy $63.98 \%$ of the Cajuri city. Cultivated areas continue to use the land and fill $32.65 \%$ of the municipal space, in which the annual, coffee and perennial crops has 985.31 ha, 865.95 ha and 861.49 ha, in order. Finally, the urban perimeter of the municipality occupies area of 85.79 ha and represents $1.03 \%$ of the territory (Table 2).

\section{Discussion}

Kappa index and global accuracy values highlight the quality of the manual classification performed and the high concordance of the digital information with the field observations, as highlighted by Landis and Koch (1977). This result was superior to those found by Ribeiro et al. (2014) (kappa index $=0.98$ ), Silva et al. (2018) (kappa index $=0.58$ ) and Machado and Rodrigues (2020) (kappa index $=0.85$ ) in the supervised classification of the land use.

The $2.31 \%$ of unclassified area (Table 2) can be explained by the difference of spatial resolution between the Sentinel-2A image and the vectorization used in the delimitation of areas (Rambo et al., 2019, Bras et al., 2021) and by nonpredominant targets and not included in the classes here defined, such as the presence of access roads (paved and vicinal).

The large area of the Cajuri city occupied with pasture reaffirms the importance of dairy farming in the municipality's economy, as highlighted by Fialho et al. (2016), by Freitas et al. (2018) and by Pereira et al. (2018). These results and the presented by IBGE $\mathrm{CA}^{\mathrm{a}}$ (2021) show an increase of $54.2 \%$ in the Cajuri pasture areas in the last 14 years.

Agricultural Census 2017 (IBGE CA $^{\mathrm{b}}$, 2021) estimate that these pasture areas are used by approximately 2,457 thousand animals, including beef and dairy cattle. In addition, reports from the Minas Gerais Company of Technical Assistance and Rural Extension point out that between 2017 (1,334 thousand liters) and 2018 (3,600 thousand liters) the milk production in Cajuri increased by $169 \%$ and that between 2018 and 2019 this production was maintained (EMATER, 2019, EMATER, 2020). 
Land use by pastures in Cajuri city is less than the average for the Minas Gerais administrative area - in which the Agricultural Census 2017 (IBGE CA ${ }^{\mathrm{b}}$, 2021) pointed a value of $45 \%$ - however, its significant presence in areas destined to the conservation of the natural resources (Federal Law No. 4,771/65) has reservations regarding the sustainability of the economic activity over time (Miranda et al., 2021). Hill tops areas, using the methodology proposed by Silva et al. (2017), and regions with a slope greater than $45^{\circ}$ were not found in the Cajuri city, but the pastures currently occupy $40 \%$ (421.84 hectares) of the areas close to the main water resources and springs.

Replacements of the natural areas by other land uses must be planned and controlled so that the environmental impacts caused do not limit the natural resources available in the long term, ensuring sustainable activity (Oliveira et al., 2020). Isolation and conservation of the riparian PPA followed by the conduction of water to animals outside this environmental perimeter is an alternative for farmers to balance economic and environmental actions in the city (Barichello et al., 2015).

Furthermore, it eases to know that local EMATER is aware of the environmental problem and that it has been proposing a series of projects such as environmental education activities, mitigating actions for environmental impacts, improving the management of dairy farming and others - to prevent possible damages of the pastures on the environment (EMATER, 2019). The monitoring of the activities over time is important to assess the effectiveness of the proposed actions.

Native forest is the second largest class in the municipality's landscape and, although present in all territorial extensions, the largest fragments of natural forests show concentrated in the northcentral region of Cajuri (Figure 2), a region where there is the Nô da Silva environmental protection area. Ecological reserve Nô da Silva is registered in Municipal Law No. 415 of February 18, 2003, occupies an area of $1,823.85$ ha $(21.96 \%$ of the territory of Cajuri) and saves approximately $32 \%$ of the natural vegetation cover of Cajuri, with large ecological corridors.

The correlation of the current data (Table 2 ) with others available in the literature shows an increase of $66.19 \%$ in the area of natural forests in the last 26 years in the city - the area of natural forest was $1,436.17$ ha in 1994, according to Coelho et al. (2005) - and this result is in line with those reported by Alves et al. (2018), in which it was observed an increase of $42 \%$ in the semideciduous seasonal forest areas of the Turvo river watershed, between 2003 and 2016, in which the Cajuri city is inserted.

The natural forest coverage index here observed is higher than that presented by the SOS Mata Atlântica institute for the Cajuri city (7\%) (FUNDAÇÃO SOS MATA ATLÂNTICA, 2017), that recommended by the United Nations ( $25 \%$ is the reference value) for development of a sustainable agriculture (Wolski, apud Quinteiro, 1997 cited by Nascimento et al., 2006 and by Oliveira et al., 2020) and that shown for the Minas Gerais administrative area (9\%) (IBGE $\mathrm{CA}^{\mathrm{b}}$, 2021), which should be highlighted. However, forest species are not always occupying the areas of environmental preservation and conservation of water resources, as provided by Federal Law No. $4,771 / 65$, and only $31.19 \%$ of the riparian regions to the main water courses and springs are occupied with forest species, which worries and shows that environmental actions should continue.

Here, the mapping of the priority areas, as carried out by Oliveira et al. (2020) for the Rio Pomba city, Minas Gerais, Brazil, and the beginning of the environmental recovery actions of these PPA is a suggestion for Cajuri. The environmental recomposition must occur with native species of the region, especially fruit species, due to their potential to attract fauna and species capable of nodulation and biological fixation of atmospheric nitrogen, to ensure the quality and quantity of water resources, biodiversity and the well-being of the populations (Cruz-Alonso et al., 2019, Sccoti et al., 2019, Costa et al., 2020).

Areas estimated here for the annual crops of Cajuri compared with data presented in the Municipal Agriculture Plan 2018 (IBGE PAM, 2018) show that the areas destined for temporary crops in the city had an increase of $31.37 \%$ in the last 2 years (the estimated area was 750 hectares in 2018). This behavior was also observed in the cities near Cajuri, except for São Miguel do Anta, in which the areas of annual crops remained constant between 2018 and 2019.

Most annual crops of Cajuri follow the intercropped system (Coutinho and Carvalho, 2019, Pereira, 2020) and, in general, these temporary crops are located in less sloping regions and close to the water courses, as illustrated in Figure 3. 


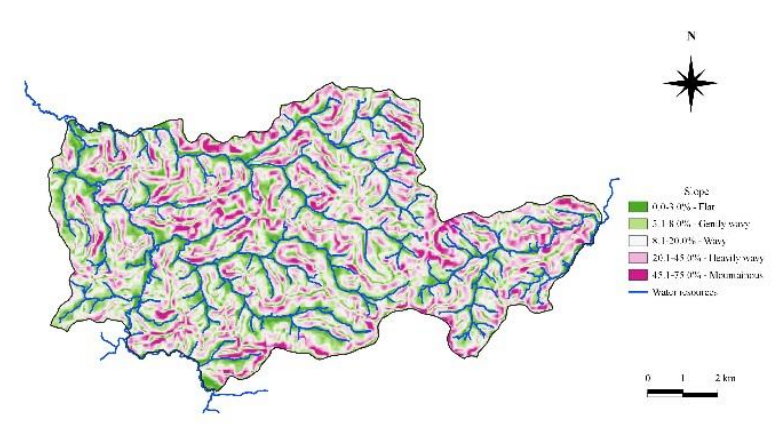

Figure 3. Geomorphology and main water resources of the Cajuri city, Minas Gerais, Brazil.

These regions of low declivity and close to the water resources are preferred by farmers in the cultivation of temporary plants given the ease they bring in the soil periodic preparation, in the cultural practices and in the adoption of irrigation (Campos et al., 2006, Oliveira et al., 2021), however, care and planning area required to not occupy the environmental preservation areas and cause conflicts.

Municipal Agricultural Plan 2019 (IBGE PAM, 2019) shows that most areas of temporary crops are used in the cultivation of maize, expected behavior given the importance of the maize in the cattle feed, and the EMATER (2020) highlights that $60 \%$ of the properties producing forage maize have a family base. Despite having the smallest area planted with maize, Cajuri recorded the second highest productivity among neighboring cities, with a productivity of 4.80 tons per hectare in 2019 (IBGE PAM, 2019).

Bean cultivation occurs between the maize crops and Agricultural Census 2017 (IBGE CA $^{\mathrm{b}}$, 2021) points out that approximately $2 / 3$ of all production is of the red type and the remaining is of the black color. In 2019, total revenue from bean cultivation in Cajuri was lower than that of the neighboring cities ( $\mathrm{R} \$ 647,000.00$ for Cajuri, $\mathrm{R} \$$ $744,000.00$ for São Miguel do Anta, R\$ $1,089,000.00$ for Viçosa and $\mathrm{R} \$ 4,758,000.00$ for Coimbra) and this information opens space for activity reflection given the potential and socioeconomic importance that the bean culture can bring to Cajuri.

Tomato is the most prominent horticulture in the city and has great collaboration with family farming (Pereira et al., 2018, Ridolfi et al., 2018). EMATER (2019) and EMATER (2020) observed an increase of $8.33 \%$ in tomato production in Cajuri between 2018 and 2019 (production of
2,400 tons in 2018 and 2,600 tons in 2019) and data from the Municipal Agricultural Plan 2019 (IBGE PAM, 2019) show that Cajuri has the second largest planted area among the neighboring cities (São Miguel do Anta has 7 ha, Viçosa has 12 ha, Cajuri has 35 ha and Coimbra with 65 ha) and the lowest tomato productivity (Cajuri with 60 ton.ha${ }^{1}$, São Miguel do Anta with 65 ton.ha ${ }^{-1}$, Coimbra with 70 ton.ha ${ }^{-1}$ and Viçosa with 75 ton.ha ${ }^{-1}$ ). The numbers show the importance of technical assistance and qualification of farmers to achieve greater productivity and also for adapting the tomato crop to the demands of sustainable production and food security, as highlighted by Ridolfi et al. (2018) and Silva et al. (2020).

Coffee production is a historic activity in Cajuri, crops are distributed in all the municipal territory, as can be seen in Figure 2, and the areas occupied with coffee have been growing in recent years. IBGE PAM (2016) recorded 750.00 ha, IBGE PAM (2019) reported 773.00 ha and the present study estimated 865.95 ha of area occupied with coffee crops in the city, an increase of $15.46 \%$ in planted area in the last 3 years.

EMATER reports indicate production of 17,000 bags (of $60.00 \mathrm{~kg}$ each) of processed coffee in 2018 and 2019 in Cajuri city (EMATER, 2019; EMATER, 2020), an activity that mobilizes around 170 family farmers, 10 non-family producers and employs many rural workers, mainly in the coffee harvest.

Cajuri's management, through Municipal Law No. 671/2017, has assisted farmers with coffee seedlings and lime, an initiative that helps to understand the increase in the planted areas and shows the managers' understanding for this activity of great socioeconomic importance for the city. In addition, this increase in the areas occupied by coffee trees was also observed in the neighboring municipality of Viçosa, in a study performed by Costa et al. (2013) in the São Bartolomeu river watershed.

Ferreira et al. (2018) highlight that geomorphology and climatic conditions favor coffee growing in Cajuri and in the field visits was observed the supremacy of the Coffea arabica, in line with the observed by Silveira (2015), and of the crops management in monoculture systems, in disagreement with reports of Vilela and Rufino (2010) cited by Pereira (2018).

Among the perennial crops studied, eucalyptus and sugar cane crops are distributed in all the territory of Cajuri, while the areas occupied with banana and heart of palm are concentrated in the central region of the city (Figure 2). The areas 
occupied with eucalyptus increased $42.59 \%$ in the last 5 years in Cajuri, in which IBGE PEVS (2020) recorded 500 ha of cultivated area in 2015 and the present paper estimated 712.96 ha. Gripp Júnior et al. (2010), Costa, et al. (2013) and Pinto (2019) observed similar behavior in areas neighboring the Cajuri city and Vale (2004) and Castro et al. (2020) highlights the support of the forest development programs and of the Ubá furniture sector in this scenario currently observed in the region.

Banana cultivation also grew in the city, with an increase of $48.05 \%$ in the planted area between 2019 ( 55 ha of cultivated area according to IBGE PAM, 2019) and 2020 (81.43 ha estimated in the present mapping) (Table 2) and of $4.30 \%$ in the banana production in 3 years (395 and 412 tons saved in the Agricultural Census 2017 and the IBGE PAM 2019, in order). Banana cultivation can be an interesting option in the diversifying of the income of the rural farmers, as highlighted by Barros et al. (2016) and Brito et al. (2020), and greater banana production is expected in Cajuri in the coming years, given the recent increase in the planted area.

The sugar cane areas had a considerable increase when compared to the 5.0 ha registered in the Agricultural Census 2017 (IBGE CA ${ }^{\mathrm{b}}, 2021$ ), adding an increase of $878 \%$ in the planted area of the crop. Agricultural Census 2017 (IBGE CA ${ }^{\mathrm{b}}$, 2021) brings sugar cane in only 4 rural properties and the field surveys carried out showed more sugar cane crops in the Cajuri territory, generally of small dimensions. These small areas combined increase the value of the cultivated area and explain the divergences in the quantities presented.

The area occupied by hearts of palm is 18.22 ha (Table 2), however, no crop data was found in municipal, state or federal agricultural reports for data comparison. The heart of palm cultivation was observed in only one rural property, located in the central region of the city, and the attention of public agencies for the crop should be highlighted since field inspections revealed that the activity is not recent and that investments, such as the installation of an agroindustry to process the product, has been carried out.

Citrus, culture that in the past was among the main agricultural activities of Cajuri (Fialho et al., 2016, Pereira et al., 2018, Freitas et al., 2018, Coutinho, 2019), had a marked reduction in their occupation areas and this event was a challenge for mapping land use. The reduction in the citrus culture can be explained by the decree of the Agricultural Institute of Minas Gerais (IMA), published in 2000, which stopped agricultural activity by contaminating seedlings with nematodes and by the decrease in the financial return of the activity for producers. The spatial resolution of the Sentinel-2A satellite image used in the classification justifies the difficulty detailing the few and small citrus areas in Cajuri.

It is believed that there were minimal variations of the urban area value in the last 10 years since IBGE estimates show a decrease of $1.80 \%$ (4047 people in the Census 2010 and 3974 people estimated in 2020) in the Cajuri population.

It should be noted that the present paper sought to map the predominant land uses, however in Cajuri there are other occupations that contribute to the filling of the space, such as cassava, mango and vegetable crops, animal husbandry areas, rural buildings and others. Besides, the results and discussions presented allow us to observe an increase in the areas of all the mapped classes (Figure 2 and Table 2) and leads us to the conclusion that these advances occurred in the suppression mainly of the citrus crops that they had in the municipality.

\section{Conclusion}

1. The mapping of land use, by geotechnologies, and its correlation with historical records allowed us to analyze the recent transformations in the landscape of the Cajuri city, Minas Gerais, Brazil. Pasture, native forest, annual and perennial crops and coffee areas have been expanded in recent years and this evolution occurred mainly in substitution of the citrus crops. The urban area has shown minimal changes in recent years.

2. The advancement of land uses over environmental preservation areas deserves attention and planning so as not to compromise the sustainability of the economic activities over time.

3. This paper details the dynamics of land use in the municipality of Cajuri and can be used in other strategic studies to improve the quality of life and well-being of the local community.

\section{Acknowledgements}

Cajuri City Hall and the Company of Technical Assistance and Rural Extension of the Minas Gerais (EMATER-MG) by the information made available, and Bruno Martins for the help with computational tools. 


\section{References}

Alves, I. R., Amaral, C. H. D., Gleriani, J. M., Cabral, I. F. Q., 2018. Spatial dynamics of semideciduous seasonal forests: Case study in the Turvo Sujo river basin in southeastern Brazil, between the years of 2003 and 2016. Brazilian Journal of Forest Science 42, 1-9. http://dx.doi.org/10.1590/180690882018000500007

Aragão, H. G, 2020. Development of a geographic Web information system (Web SIG) for the basic sanitation area using free technologies. Brazilian Journal of Development, 6, 68356840. https://doi.org/10.34117/bjdv6n2-108

Barichello, D. E., Pinheiro, D. K., Rorato, D. G., 2015. Ações práticas e de educação ambiental visando preservar nascentes, Dona Francisca, RS. Revista Monografias Ambientais 14, 64-75. https://doi.org/10.5902/2236130817705

Barros, A. C. D., Tagliarini, F. D. S. N., Garcia, Y. M., Minhoni, R. T. D. A., Barros, Z. X. D., Zimback, C. R. L., 2019. Mapeamento da aptidão agrícola das terras por meio de análise multicritério. Revista de Ciências Agrárias 42, 1-10. http://dx.doi.org/10.19084/rca.17293

Barros, E. C. S., Inácio, R. A., Pinto, F. O., Da Silva Quintas, E., Rodrigues, M. D., 2016. A utilização da banana como fonte de renda para pequenos produtores. LSP - Interdisciplinary Scientific Journal 3, 22-37. http://dx.doi.org/10.17115/2358-8411/v3n2a2

Borges, M. G., Rodrigues, H. L. A., Leite, M. E., 2017. Mapeamento de fitofisionomias do Cerrado na microrregião de Grão Mogol através de imagens de satélite Landsat 8 e Sentinel-2A. Revista Tocantinense de Geografia 6, 19-30. https://doi.org/10.20873/rtg.v6n11p19-30

Bras, A. M., Korting, T. S., Martins, A. P., Bras, A. M., 2021. Geobia e mineração de dados para classificação de imagens de altíssima resolução espacial. Estudos Geográficos: Revista Eletrônica de Geografia, 19, 209-224. https://doi.org/10.5016/estgeo.v19i3.16254

Brito, E. M., De Mello, K., Da Costa, D. R., De Faria, L. C., Valente, R. A., 2016. Geotecnologias aplicadas ao estudo do conflito de uso do solo visando o planejamento ambiental. Irriga 21, 577-590. https://doi.org/10.15809/irriga.2016v21n3p577 $\underline{-590}$

Brito, I. C. G., Neto, A. F., Farias, M. S. R., 2020. Cost of production and economic performance of pacovan banana in the irrigated perimeter of
Ponto Novo-BA, Custos e @gronegócio on line, 16, 207-232

Campos, C. E. B., Lani, J. L., Alves, M. R., Mendonça, R. F., Amaral, E. F., 2006. Uso das várzeas úmidas (brejos) e aspectos pedosociais: Estudo de caso em Cajuri-MG. Revista Ceres 53, 519-527

Cândido, A. K. A. A., Da Silva, N. M., Paranhos Filho, A. C., 2016. Imagens de alta resolução espacial de veículos aéreos não tripulados (VANT) no planejamento do uso e ocupação do solo. Anuário do Instituto de Geociências 38, 147-156. http://dx.doi.org/10.11137/2015_1_147_156

Castro, V. R., Costa, L. J., Almeida Filho, W. R., 2020. Profile of sawmills in the Ubá furniture hub in the state of Minas Gerais. Revista Engenharia na Agricultura, 28, 245-254. https://doi.org/10.13083/reveng.v28i.8520

Coelho, D. J. D. S., Souza, A. L. D., Oliveira, C. M. L. D., 2005. Levantamento da cobertura florestal natural da microrregião de Viçosa, MG, utilizando-se imagens de Landsat 5. Revista Árvore 29, 17-24. http://dx.doi.org/10.1590/S010067622005000100003

Cohen, J., 1960. A coefficient of agreement for nominal scales. Educational and Psycological Measurement. 20, 37-46. https://doi.org/10.1177/001316446002000104

Costa Junior, J. M., Oliveira, J. J. L., Vieira, E. M., Silva, W. S., Paula, R. P., 2018. Análise da Assistência Técnica e Extensão Rural em Municípios do Cariri Cearense. Cadernos de Agroecologia 13, 1-10

Costa, S. P., Martins, R. A., Santos, E. V., Sousa, A. T., Nogueira, P, H. S., Oliveira, R. S., Silva, H. M. M., Brito, J. M. G., 2021. Análise da dinâmica do uso da terra nas Áreas de Preservação Permanentes na microbacia do Ribeirão da Serra no Munícipio de Morrinhos GO. Brazilian Journal of Development, 7, 4117-4131. https://doi.org/10.34117/bjdv7n1278

Costa, T. A., Soares, V. P., Ribeiro, C. A. A. S., Gleriani, J. M., 2013. Dinâmica do uso e ocupação da terra na microbacia do Ribeirão São Bartolomeu-Viçosa, MG. Revista Agrogeoambiental 5, 97-108. http://dx.doi.org/10.18406/2316$1817 \mathrm{v} 5 \mathrm{n} 22013480$

Costa, T. G. A., Iwata, B. F., Rocha, I. L., Souza, I. R. M., Porto, S. T. R., Alves, A. S., 2020. Diagnosis and proposal for the recovery of degraded area under physionomy of cerrado in 
current - Piauí. Brazilian Journal of Development, $\quad 6, \quad 93976-93989$. https://doi.org/10.34117/bjdv6n12-020

Coutinho, E. A. C., Carvalho, A. L. F., 2019. Mobilidade cotidiana campo-cidade nas sociedades rurais em Cajuri e Coimbra/MG. Revista Nera, 22, 59-82. https://doi.org/10.47946/rnera.v0i49.5863

Cruz-Alonso, V., Benito, P. R., Salvador, P. V, Benayas, J. M. R., 2019. Long- term recovery of multifunctionality in Mediterranean forests depends on restoration strategy and forest type. Journal of Applied Ecology, 56, 745-757. https://doi.org/10.1111/1365-2664.13340

EMATER Empresa de Assistência Técnica e Extensão Rural Do Estado De Minas Gerais, 2019. Relatório Anual de Ações de Assistência Técnica e Extensão Rural: Ano 2018. (Relatório anual da EMATER-MG Cajuri, 2019).

EMATER. Empresa de Assistência Técnica e Extensão Rural Do Estado De Minas Gerais, 2020. Relatório Anual de Ações de Assistência Técnica e Extensão Rural: Ano 2019. (Relatório anual da EMATER-MG Cajuri, 2020).

Fernandes, M. M., Ker, J. C., Rezende, S. B., 2007. Delineamento semi-detalhado de solos empregando aerofotos não-convencionais na sub-bacia palmital - Rio Turvo Sujo (MG). Geonomos 15, 01-07. https://doi.org/10.18285/geonomos.v15i2.93

Ferreira, G. R., Ferreira, W. P. M., Barbosa, T. K. M., Luppi, A. S. L., Silva, M. A. V., 2018. Thermal zoning for mountain coffee crops in the Matas de Minas region, Brazil. Revista Brasileira de Geografia Física 11, 1176-1185. https://doi.org/10.26848/rbgf.v11.4.p1176$\underline{1185}$

Ferreira, L. M. R., Esteves, L. S., Souza, E. P., Santos, C. A. C., Rego, V. G. S., 2019. Mudanças no espaço temporal da disponibilidade de serviços ecossistêmicos em uma microbacia hidrográfica do nordeste brasileiro. Desenvolvimento e Meio ambientes 52 , 155-174. http://dx.doi.org/10.5380/dma.v52i0.57716

Fialho, E. S., Junior, E. C., Quina, R., 2016. O campo térmico em situação episódica de primavera em uma cidade de pequeno porte, na zona da mata mineira: Um estudo de caso em Cajuri-MG. Revista de Geografia 33, 299-318

Folharini, S. O., Souza, S. O., 2019. Mapeamento do uso e ocupação da terra do município de Petrolina (PE) - médio vale do rio São Francisco através do NDVI de imagem Landsat 8 (OLI). Revista Equador 8, 489-502
Freitas, G. A., De Moura, B. V. M., Pereira, O. G., Marcondes, M. I., 2018. Custo de produção de silagem de milho em fazendas leiteiras na região de Viçosa-MG. Nutri time Revista Eletrônica 15, 8321-8330

Fundação SOS Mata Atlântica, 2017. Atlas dos remanescentes florestais da Mata Atlântica: Período 2015-2016. (Relatório técnico da Fundação SOS Mata Atlântica e do Instituto Nacional de Pesquisas Espaciais, 2017)

Furtado, L. G., Morales, G. P., Silva, D. F., Pontes, A. N., 2020. Transformações do uso e cobertura da terra na bacia hidrográfica do rio Murucupi, Barcarena, Pará. Revista Brasileira de Geografia Física 13, 2340-2354. https://doi.org/10.26848/rbgf.v13.5.p23402354

Gripp Junior, J., Soares, V. P., Ribeiro, C. A. Á. S., Souza, A. L. D., Gleriani, J. M., 2010. Use of geoprocessing techniques for mapping Permanent Preservation Areas (PPAs) and Legal Reserve Areas (LRA) in farms. Revista Ceres 57, 459-468

Haetinger, C., Rempel, C., Herrmann, M. F., Silva, G. R., 2021. Avaliação da Sustentabilidade Ambiental de Propriedades Rurais Produtoras de Leite. Environmental Science, 10, 153-167. https://doi.org/10.21664/22388869.2021v10i2.p153-167

IBGE CA ${ }^{\text {a }}$. Instituto Brasileiro De Geografia E Estatística, 2021. Censo Agropecuário 2006. https://cidades.ibge.gov.br/brasil/mg/cajuri/pes quisa/24/76693?ano=2006 Accessed July 1, 2021

IBGE CA ${ }^{\mathrm{b}}$. Instituto Brasileiro De Geografia E Estatística, 2021. Censo Agropecuário 2017. https://censoagro2017.ibge.gov.br/templates/ce nso_agro/resultadosagro/index.html Accessed: July 1, 2021

IBGE PAM. Instituto Brasileiro De Geografia E Estatística, 2016. Produção Agrícola Municipal 2016. Instituto Brasileiro de Geografia e Estatística 43, 1-64.

IBGE PAM. Instituto Brasileiro De Geografia E Estatística, 2018. Produção Agrícola Municipal 2018. Instituto Brasileiro de Geografia e Estatística 45, 1-8

IBGE PAM. Instituto Brasileiro De Geografia E Estatística, 2019. Produção Agrícola Municipal 2019. Instituto Brasileiro de Geografia e Estatística 46, 1-8

IBGE PEVS, Instituto Brasileiro De Geografia E Estatística, 2020. Produto da Extração Vegetal e da Silvicultura 2015. Instituto Brasileiro de Geografia e Estatística, 
https://sidra.ibge.gov.br/tabela/5930, Accessed: April 10, 2020

IBGE, Instituto Brasileiro De Geografia E Estatística. IBGE Cidades: Cajuri. Instituto Brasileiro de Geografia e Estatística, https://cidades.ibge.gov.br/brasil/mg/cajuri/pan orama. Accessed: Nov 28, 2021.

Justino, R. C., Mataveli, G. A. V., Kawakubo, F. S., Guerrero, J. V. R., Chaves, M. E. D., 2019. Mapeamento do uso da terra e áreas de preservação permanente (APP) nas bacias hidrográficas dos rios São Tomé e Machado, sul de Minas Gerais. Revista de Geografia 9, 50-65.

Landis, J., Koch, G., 1977. The measurement of observer agreement for categorical data, Washington, USA. Biometrics 33, 159-174. https://doi.org/10.2307/2529310

Leite, M. E., Leite, M. R., Clemente, C. M. S., 2010. O uso do solo e o conflito por água no alto rio Riachão - norte de minas gerais: uma análise Auxiliada pelas geotecnologias. Revista Geográfica Acadêmica 4, 46-55

Machado, A. M. B., Rodrigues, T. C. S., 2020. Comparação de métodos de classificação para o mapeamento da cobertura da terra no setor norte da Ilha do Maranhão. Geosciences = Geociências, 39, 1129-1140. https://doi.org/10.5016/geociencias.v39i04.141 $\underline{28}$

Maidjelele, G. B. A., Pacheco, J. A. A., Drummond, J. A. L., Silva, E. V., Carlos, D. A. I., Martorano, L. G., 2020. Proposta de planejamento de uso e ocupação do solo a partir de análise espaço-temporal com imagens orbitais do município de Chimoio, Moçambique. Brazilian Journal of Development, 6, 84952-84965. https://doi.org/10.34117/bjdv6n11-056

Miranda, E., Carvalho, C. A., Martinho, P. R. R., Oshiro, O. T., 2020. Contribuições Do Geoprocessamento À Compreensão Do Mundo Rural E Do Desmatamento No Bioma Amazônia. Colóquio-Revista Do Desenvolvimento Regional 17, 16-34. https://Doi.Org/10.26767/Coloquio.V17i1.157 $\underline{6}$

Miranda, R. F., Botezelli, L., Pamplin, P. A. Z., 2021. Conservação ambiental em zonas ripárias de dois córregos urbanos no município de Três Pontas, sul de Minas Gerais. Research, Society and Development, 10, e303101321184e303101321184. https://doi.org/10.33448/rsdv10i13.21184

Nascimento, M. C., Riva, R. D., Chagas, C. D. S., Oliveira, H. D., Dias, L. E., Fernandes Filho, E.
I., Soares, V. P., 2006. Uso De Imagens Do Sensor Aster Na Identificação De Níveis De Degradação Em Pastagens. Revista Brasileira De Engenharia Agrícola E Ambiental 10, 196$202 . \quad$ Http://Dx.Doi.Org/10.1590/S1415$\underline{43662006000100029}$

Neto, A. G. P., Barbosa, I. M. B. R., Faustino, R., 2019. Geoprocessamento Aplicado Ao Uso E Ocupação Do Solo Da Zona De Conservação De Corpos D'água No Município Do Jaboatão Dos Guararapes-Pe. Mix Sustentável 5, 99-107. https://Doi.Org/10.29183/24473073.Mix2019.V5.N2.99-107

Oliveira, J. A., Silva, J. B., Ribeiro, K. M., Ferreira, F. M. C., Silva, R. R. S., 2020. Mapping Of Priority Areas For Environmental Recovery Of Rio Pomba City, Minas Gerais. Revista Brasileira De Geografia Física 13, 1792-1801. https://Doi.Org/10.26848/Rbgf.V13.4.P1792$\underline{1801}$

Oliveira, J. D., Sousa, J. B., Souza, C. A., 2021. Unidades geoambientais da bacia hidrográfica do rio Branco no sudoeste do estado de Mato Grosso. Revista Equador, 10, 183-206

Pereira, A. J., 2018. Diversidade Vegetal E Dinâmica De Alocação De Mão De Obra Na Cafeicultura Familiar Da Zona Da Mata De Minas Gerais. Universidade Federal De Viçosa. http://Www.Sbicafe.Ufv.Br/Handle/12345678 9/12491

Pereira, A. J., Santos, R. H. S., Santana, F. C., 2020. Uso Da Mão De Obra Na Ocupação Do Solo Pela Pluriatividade Da Agricultura Familiar. Cadernos De Agroecologia 15, 1-5.

Pereira, L. F., Guimarães, R. M. F., 2018. Mapeamento Multicategórico Do Uso/Cobertura Da Terra Em Escalas Detalhadas Usando Semi-Automatic Classification Plugin. Journal Of Environmental Analysis And Progress 3, 379385.

Https://Doi.Org/10.24221/Jeap.3.4.2018.2016. 379-385

Pinto, M. G. F., 2019. Análise Temporal Da Cobertura E Uso Da Terra Como Subsídio Ao Estudo De Degradação Ambiental Em São Miguel. Universidade Federal De Viçosa

Qgis, D. T., 2021. Quantum Gis Geographic Information System. Open Source Geospatial Foundation Project, 45

Rambo, E. M., De Albuquerque Silva, L. C., Becker, W. R., Richetti, J., Bortolini, J., Johann, J. A., Mercante, E., 2019. Processamento E Classificação De Imagens Landsat-8 Para Uso E Ocupação Do Município De Tupãssi-Pr 
Utilizando O Google Earth Engine. [Paper Presentation]. Xix Simpósio Brasileiro De Sensoriamento Remoto. Santos, São Paulo, Brasil

Reis, A. M., Ribeiro, M. B. A., 2016. Integração Regional Como Meio De Formação De Uma Consciência Ambiental Para O Desenvolvimento Sustentável Das Futuras Gerações. Revista Brasileira De Direito Internacional 214-232. Https://Doi.Org/10.21902/

Ribeiro, C. A. A. S., Lemos, N. D. C. M., De Oliveira Barros, K., Soares, V. P., Silva, E., 2014. Áreas De Preservação Permanente Em Conflito Com O Uso E A Ocupação Do Solo Na Bacia Hidrográfica Do Córrego Sertão, Cajuri, Minas Gerais. Revista Agrogeoambiental 6, 2129.

Http://Dx.Doi.Org/10.18406/23161817v6n220 14635

Ridolfi, A. R. C., Oliveira, M. L. R., Araújo, L. F., Souza, F. L., 2018. Desafios Da Pesquisa Sobre O Uso De Agrotóxicos Na Tomaticultura Por Agricultores Familiares. Cadernos De Agroecologia 13, 1-5

Santos, H. G., Jacomine, P. K. T., Anjos, L. H. C., Oliveira, V. A., Lumbreras, J. F., Coelho, M. R., Almeida, J. A., Araújo Filho, J. C., Oliveira, J. B., Cunha, T. J. F., 2013. Sistema Brasileiro De Classificação De Solos. Embrapa Solos

Sccoti, M. S. V., Jesus, M. G., Possimoser, D., Biazatti, S. C., Brito Junior, J. F., 2019. Evaluation And Potential Use Of Native Forest Species In The Recovery Of A Legal Reserve In The Western Amazon. Revista Agro@Mbiente On-Line 13, 232-242. Http://Dx.Doi.Org/10.18227/19828470ragro.V13i0.5615

Silva, G. B. S., Betiol, G. M., Sano, E. E., 2018. Análise Comparativa De Quatro Métodos De Classificação Supervisionada Para A Discriminação De Fitofisionomias De Cerrado. Geografia, Ensino \& Pesquisa 12, 3935-3947. Http://Dx.Doi.Org/10.18764/24466549.V4n13p26-44
Silva, J. N., Araújo, T. C., Ponciano, N. J., Souza, C. L. M., 2020. Diagnóstico do uso de agrotóxicos por tomaticultores do município de São José de Ubá, RJ. Revista Brasileira de Agropecuária Sustentável, 10, 45-50. https://doi.org/10.21206/rbas.v10i1.8579

Silva, J., Wegner, N., Osman, Y., Alves, A., 2017. Delimitação De Áreas De Preservação Permanente Em Topo De Morro Utilizando O Qgis. [Paper Presentation] Xvii Simposio Internacional En Percepción Remota Y Sistemas De Información Geográfica. Puerto Iguazú, Misiones, Argentina

Silva, L. S., Moreau, M. S., Daltro, U. S., 2020. Uso Do Geoprocessamento Para Mapeamento Do Uso E Ocupação Do Solo Com Ênfase Em Métricas Da Paisagem: Um Estudo De Caso Na Bacia Hidrográfica Do Rio Água Branca. Revista Acta Ambiental Catarinense 17, 33-44. Http://Dx.Doi.Org/10.24021/Raac.V17i1.5035

Silva, M. F., Gameiro, A. H., 2021. Indicadores de sustentabilidade para a produção de leite: uma revisão de literatura. Revista Livre de Sustentabilidade e Empreendedorismo, 6, 208237

Silveira, A. S., 2015. Atributos Sensoriais Dos Cafés Cultivados Em Diferentes Altitudes E Faces De Exposição Na Região Das Matas De Minas. Universidade Federal De Viçosa. Http://Www.Sbicafe.Ufv.Br:80/Handle/12345 6789/8330

Vale, R. S., 2004. Agrossilvicultura Com Eucalipto Como Alternativa Para O Desenvolvimento Sustentável Da Zona Da Mata De Minas Gerais. Universidade Federal De Viçosa

Vivas, F. N. e Nunes, J. O. R., 2018. Recuperação De Áreas Degradadas Em Propriedade Rural No Município De Ceres-Go. Cipeex 2, 13051315. 